\title{
Palaeobiogeographical and Paleoenvironmental Study of the Middle-Upper Jurassic Corals in East-Central Iran Carbonate Platform
}

\author{
Kaveh Khaksar,", Keyvan Khaksar ${ }^{2}$ \\ ${ }^{1}$ Department of Soil and Water, Institute of Scientific Applied Higher Education of Jihad-e-Agriculture, Education and Extension \\ Organization, Ministry of Agriculture Karaj-Iran \\ ${ }^{2}$ Faculty of Basic Sciences, Qom Branch, Islamic Azad University, Qom, Iran \\ *Corresponding author: kavehkhaksar@gmail.com
}

Received May 30, 2014; Revised July 24, 2014; Accepted September 22, 2014

\begin{abstract}
This research gives a general outline of the Middle-Upper Jurassic sequences cropping out Central-East Iran. Jurassic rocks are spread widely in central-East Iran. In the Jurassic, East-Central Iran carbonate Platform, in the aspect of biogeography, has been located in the north of Gondwana paleocontinent and near northern margin of Paleo Tethys Ocean. The corals of the Jurassic of the Iranian carbonate platform have been compared with the Jurassic corals of the other provinces of the world. The whole assemblage of Iran show higher similarity with the Europe and South Asia Provinces assemblages. The Central East Iranian corals dominantly formed by colonies and belongs to reefal environment.
\end{abstract}

Keywords: jurassic, corals, paleogeography, paleoecology, central-east iran

Cite This Article: Kaveh Khaksar, and Keyvan Khaksar, "Palaeobiogeographical and Paleoenvironmental Study of the Middle-Upper Jurassic Corals in East-Central Iran Carbonate Platform.” American Journal of Environmental Protection, vol. 2, no. 5 (2014): 79-82. doi: 10.12691/env-2-5-1.

\section{Introduction}

Lias and early Douger Rocks of Iran, have close affinity with upper Triassic deposits. Moreover, upper Jurassic rocks of Iran are somehow related to deposits in early Cretaceous. Paleogeographical studies of Jurassic in Iran, indicates that Iran country has been included two dependent zones in this period which have been separated from each other along approximate location of major thrust Zagros. Types of rocks and fossils in this zone have significant differences and so study of Jurassic in Iran in two plates; Iran (Alborz, Central Iran and KopetDagh) and Zagros plate, can be representative of stratigraphic characteristics of this system. A part of Jurassic rocks of Iran has magmatic origin. Lower Jurassic rocks of Iran have good resources of coal, hydrocarbon and symptoms of bauxite and laterite. Also, a part of rocks in this period are useful in building industries and cements.

Impression of two tectonic events on sedimentary basins in Jurassic is considerable. First event which has occurred in middle of Douger (Bajocian - Bathonian) and is unknown yet, is named middle Cimmerian. Consequence of tectonic evolutions of this event is folding, magmatism and metamorphism and is known as an orogeney event which its effects are mainly in Sanandaj sirjan zone and particularly in Lut block. Second tectonic event in Jurassic of Iran, is known in boundary of Jurassic and Cretaceous and as a type of orogeny with folding and magmatism, but based on new geologic data from Jurassic of Iran, it can be said that on the contrary of common belief, this event has occurred in early Cretaceous (before of Barremian), not in boundary of Jurassic - Cretaceous. Moreover, this event has a land generating nature and many of tectonic revolutions, pertaining to late Jurassic period and late Cimmerian, are in reality results from folding and magmatism in middle Cimmerian which had been unknown since yet. Besides two mentioned events, there is a sedimentary disconformity which is named Tabasian event. In spite of dominance of equal sedimentary conditions on basins in Jurassic of Iranian plate, lithostratigraphic units in this period do not have same name in Alborz, Central Iran, Kopet Dagh and Sanandaj-Sirjan [1]. An alternate hypothesis is proposed here to explain the widespread occurrence of glacial deposits during the Neoproterozoic. In this model, the mystery of the Vendian Ice House world is explained by the proximity of continental masses to the North and South Poles. Ice rafted debris and glacial deposits formed on these continents as they travelled across the poles. As can be seen in (Figure 1), though some tallits are found at low latitudes (e.g. Australia), nearly $80 \%$ of the tallit localities occur at latitudes greater than $30^{\circ}$ Furthermore, Vendian evaporates and platform carbonates almost exclusively occur at latitudes less than $30^{\circ}$ (southern Arabia, Iran and India) [2].

The breakup of Pangea (or alternatively, Laurasia and Gondwanaland) began in the late Triassic, when South America and Africa began to drift apart and India separated from Africa, Australia and Antarctica. The 
counterclockwise motion of Africa closed the Tethys Ocean, while Laurasia moved in a clockwise direction. The Central East Iran microplate drifted southwards and rotated $65^{\circ}$ counterclockwise at that time [3].

\section{Study Area}

In Iranian plate (Sanandaj-Sirjan, Central Iran, Alborz and Azerbaijan), Jurassic rocks are representative of two big and independent cycles whose boundary has been attributed to tectonic events. First sedimentary cycle of Jurassic is pertaining to lower-middle Jurassic and contains coal-bearing shale and sandstone which have been deposited in lagoon and environments near to shore line and its thickness is varied from several meters to over 3,000 meters. Lower boundary of this group is identified by early Cimmerian disconformity and upper boundary with middle Cimmerian event. Second sedimentary cycle from Jurassic of Iran is composed of Ammonites-bearing limestone and marl and has been ended with red clastic strata or evaporative deposits. Rocks in this sedimentary cycle have been deposited between two tectonic events; middle Cimmerian (middle Jurassic) and late Cimmerian (early Cretaceous), so that is a sedimentary cycle in group order, named informally "Magu group".

Located as a triangle in the middle of Iran, Central Iran is one of the most important and complicated structural zones in Iran. According to [4], Central Iran is bordered by the Alborz Mountains in the north, Lut Block in the east, and Sanandaj-Sirjan in the south-southwest, whereas [5] considers the northern part of the Lut block as part of the Central Iran (Figure 1).

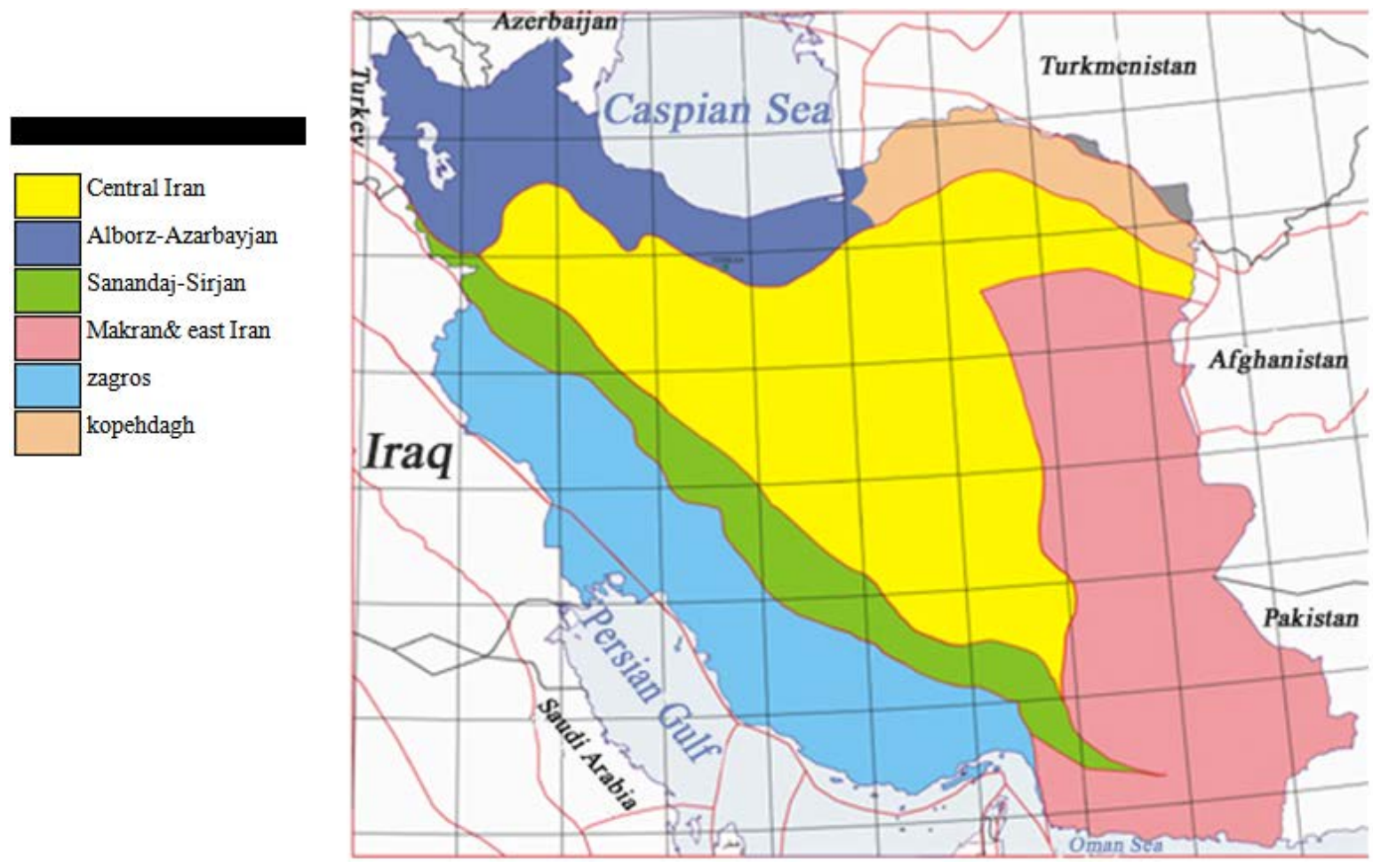

Figure 1. Structural geology of Iran

\section{Method}

\subsection{Lithology of the Studied Section}

Fossiliferous marine beds of Early Jurassic age occur in the form of thin, ammonite bearing sandstone and limestone intercalations in the plant bearing sequence, the oldest ones, of Early Liassic (Sinemurian) age, have been found in the Kerman area. Paleontological evidence for marine domerian is uncertain. A widespread marine transgression is indicator in the Toarcian-Aalenian of in the Toarcian-Bajocian (Bathonian) of the Kerman-YazdTabas area (Badamu Limestones). Calcareous deposits prevailed in the Middle-Upper Jurassic and in the Upper Jurassic (Qaleh Dokhtar F., Esfandiar Limestone in East Iran).

\subsection{Methods}

The data used in this paper are from all compiled studies that includes of all Scleractinian taxa occurring in the Jurassic of the world. For this study all of Jurassic corals of Iranian platform were investigated and correlated with all Jurassic geological provinces of the world.

\section{Results and Discussion}

The corals, which have been introduced in the Jurassic carbonate platform of Central-East Iran, are 38 genera and have been studied and introduced by [6], from the Central Iran (Shotori mountains), [1], from east-central Iran and [7] from Middle Shale Member of Qaleh-Dokhtar Formation (Tabas Area-East Iran).

The corals, which have been introduced in the Jurassic of Central Iran, are 30 genera and have been excluded corals with endemic character. Nine Provinces of coral distribution were established in the Jurassic: Europe, North America, South America, Australia, Madagascar, South-west Asia, South-east Asia, Eurasia, and Africa. Each province includes several zoogeographic areas. The Jurassic corals of Iran have been compared with Jurassic 
corals of the different provinces of the world (Table 1). As, it shows; the corals assemblages of the Central-East Iran have the most important and most similarity with 24 genera by the European Province, for this reason CentralEast Iran basin is part of European province in Jurassic paleozoogeography. East Asia with 16 genera and North Africa with 15 genera have also important similarity with Central-East Iran. West Asia and Eurasia shows more relation toward Upper Jurassic with 14 genera. North Antarctic (India) has important similarity with CentralEast Iranian basin because of 10 scleractinian genera. The similarity with the provinces of South America is with 7 genera and the common elements with provinces of northern America and Madagascar decrease with 5 genera. The farther from other provinces, like northern America and Madagascar are concurrent with the least degree of similarity.

The similarity of the Central-East Iran coral assemblage with European corals is accountable because of being near both of two areas to each other, in paleogeography, because these basins with near in north of equatorial ocean have been in the Jurassic of Tethys (Figure 2).

Table 1. The genera of Central-East Iranian basin and their distribution in the different provinces of Jurassic time

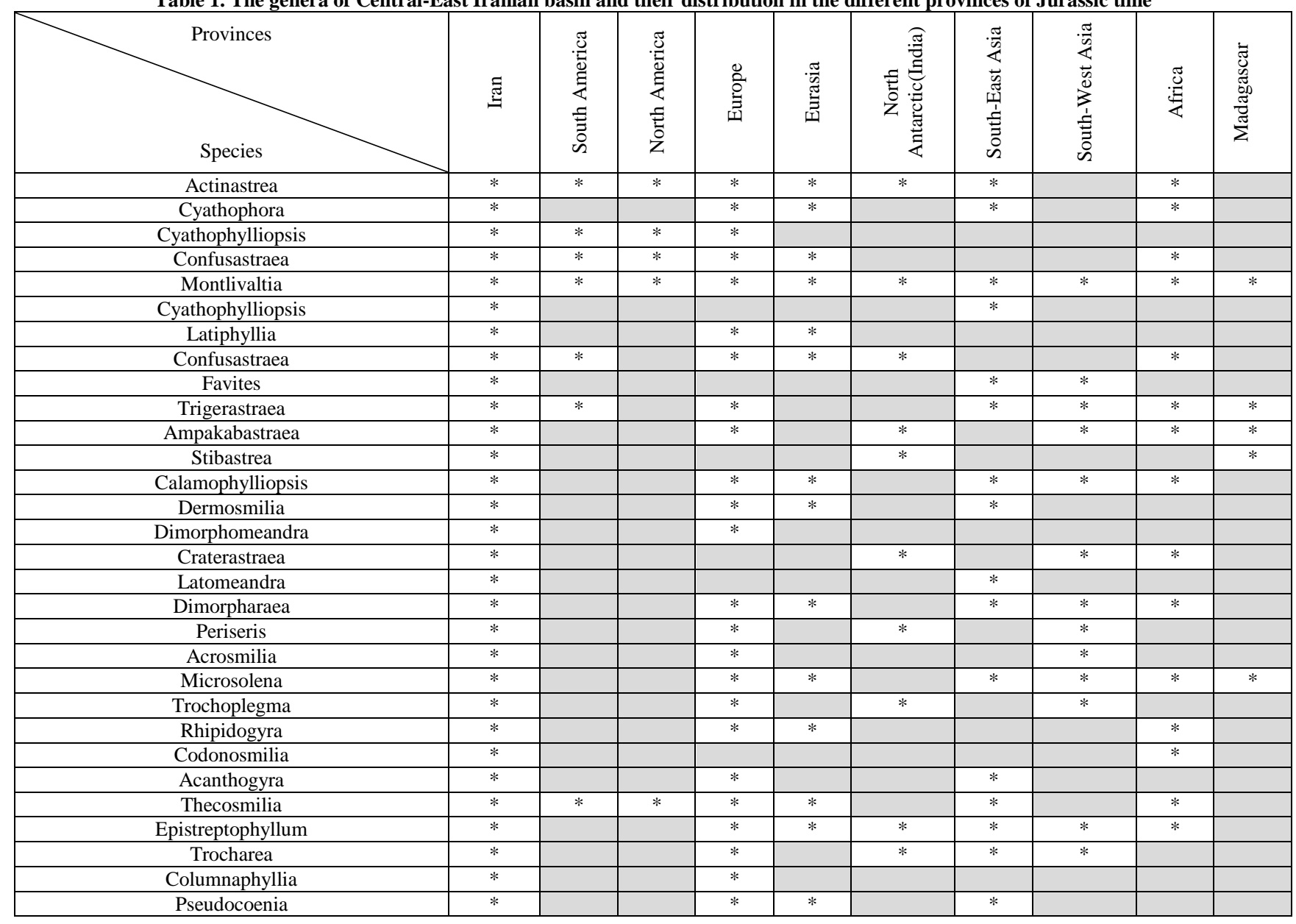

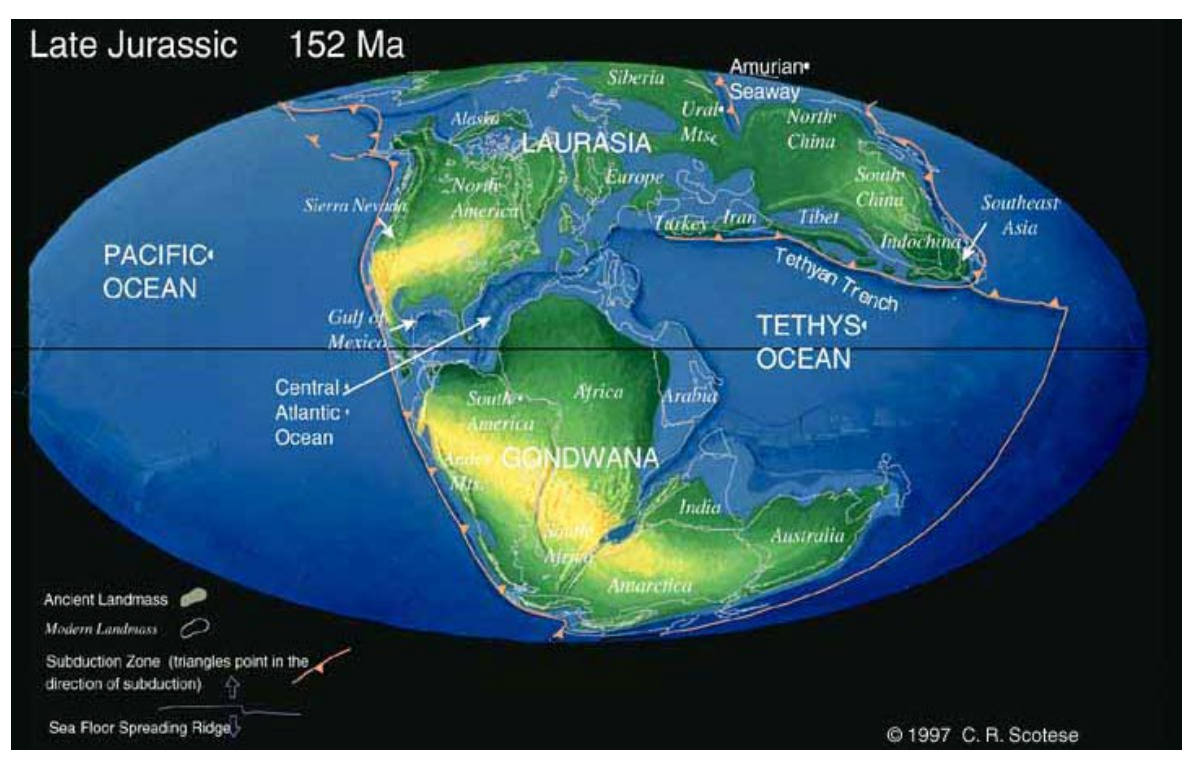

Figure 2. paleogeographical map of Late Jurassic [8] 


\subsection{Paleoenvironment}

The Central East Iranian corals dominantly formed by colonies and belongs to reefal environment. Structural and functional aspects of the reef community allow ecological comparisons to be made with contemporaneous, as well as recent, reefs.

The unique combination of ecological factors resulted in a specialized, previously undescribed, community which differs from both Tethyan and northern localities in various aspects; these include cavities with cryptofauna, prominence of grazing gastropods and high faunal diversity in a microbially dominated build-up.

Most scleractinian corals live in shallow waters (typically $50 \mathrm{~m}$ ) and they prefer clear waters with little salinity variations. Fossil scleractinian corals are in fact widely used for indicating past climatic conditions $[9,10,11]$.

These corals are similar to recent hermatypic colonial corals. The palaeoecological analysis suggests that the major controls on faunal composition and high diversity were elevated nutrient levels, highly episodic sedimentation and probably seasonal environmental disturbances. The Jurassic coral assemblage of Iran indicate that they lived in the shallow areas of carbonate platform with warm waters where limestones were deposited, absence of major rivers that bring silt and fresh water down to the sea, sufficient light and restricted to water depths of less than $70 \mathrm{~m}$.

\section{Conclusion}

In the Jurassic time Iranian platform was situated in the north of equator line and near the Eurasian platform. Corals are one kind of the most abundant Jurassic fossils in Iran, because of the best environmental conditions for growth and survival.

The Iranian coral assemblage of Jurassic have higher similarity with the European province in Jurassic paleozoogeography and is part of European province.
Paleoecologically, presence of colonial corals communities show equatorial environment covered Central-East Iranian of basin in the Middle-Upper Jurassic.

\section{References}

[1] Desmons, J., Meso-Cainozoic palaeogeography of the Middle East: constraints from the Iranian sutures, Géologie Alpine, t. 58, p. 2130, 1982.

[2] Ronov, A., Khain, V., Seslavinsky, K., Atlas of LithologicaIPaleogeographical Maps of the World, Late Precambrian and Paleozoic of Continents. USSR Academy of Sciences, Leningrad, 70p., 1984.

[3] Nabavi, M. H., An introduction to geology of Iran. (in Persian), Geological Survey of Iran, Tehran, 1976.

[4] Stocklin, J., Structural history and tectonics of Iran, A review. AAPG Bulletin 52, 7: 1229-1258, 1968.

[5] Pandey, D. K., and Fürsich, F. T. Jurassic corals of east-central Iran, Beringeria, Heft 32: 1-140, 2003.

[6] Flugel, E., Mitteljurassische korallen vom Ostrand der Großen Salzwüste (Shotori-Kette, Iran). -Neues Jahrbuch für Geologie und Palaontologie, Abhandlungen: 126. 1. 46-91, pls. 15-19; Stuttgart, 1966.

[7] Khaksar, K., Stratigraphical position of Jurassic corals from Middle Shale Member of Qaleh -Dokhtar Formation (Tabas AreaEast Iran), The 8th International Congress on the Jurassic system, August 9-13, 2010, Shehong of Suining, Sichuan, China, 2010.

[8] Scotese C. R., A continental drift 'flip book", Computers and Geology, 2:13-116, 1997.

[9] Veron, J.E.N., Corals in Space and Time: The Biogeography and Evolution of the Scleractinia. UNSW Press. 321 pp. Wilson, M.E., Rosen, B.R., 1998. Implications of paucity of corals in the Paleogene of SE Asia, Plate tectonics or center of origin? In: Hall R, Halloway JD (Eds). Biogeography and Geological Evolution of SE Asia, Backbuys Publishers, Leiden, pp 165- 195, 1995.

[10] Rosen, B.R., Paleoclimatic implications of the energy hypothesis from Neogene corals of the Mediterranean region. In: Agusti, J., Rook, L., Andrews, P. (Eds.), The evolution of Neogene terrestrial ecosystems in Europe. Cambridge University Press, Cambridge 309- 327, 1999.

[11] Bosellini, F.R., Russo, A., Biodiversitàdeicorallizooxantellati e implicazionipaleoclimatiche. L'esempiodel Paleogene Italiano. In: Cherchi, A., Corradini, C. (Eds.), CrisiBiologiche, radiazioniadattative e dinamicadellepiattaformecarbonatiche. Acc. Naz. Sci. Lett. Arti di Modena 21: 41-45, 2000. 